\title{
Importance of Sales and Marketing Departments to Overcome Most Important Threats in Retail Banking Industry
}

\author{
Daisy Gulcin Erbas \\ DBA-Management Student \\ Westcliff University \\ Irvine, CA, 92606 \\ USA
}

\begin{abstract}
Retail banking industry become more competitive. Providing regular banking needs for customers do not help retail banks to make more profits. In the competitive marketplace, retail banks need to make difference to attract more customers. Globalization, competitors, changing customer needs and technology were identified as most important threats for retail banks. All these threats are related to each other. It may not enough to take measures for just threat. It is important for managers to understand all these threats work together and ignoring one of them can have domino effect. Managers need to capable of identifying the threats before it becomes a weakness.
\end{abstract}

Keywords: Threats, Competitiveness, Competitor, Globalization, Off shoring, Outsourcing

\section{Introduction}

In recent years, retail banking industry became more competitive. There has been increase on number of retail banks. These competitiveness make banks to improve marketing campaigns to increase sales numbers. In order to be successful in the competitive market, retail banks marketing and sales department needs to overcome major threats. Globalization, increased competition in the market, changing expectations of customers, technology can be defined as the most critical threats.

\section{Globalization}

Globalization's effects on business, increased competition in the market, changing expectations of customers, technology are all work together. Globalization can have negative effects on business besides more opportunities. Zedillo (2007) stated that "Globalization only serves the interests of countries in the developed world such as United States, Europe, Australia and Canada among others. Developing countries are normally left out of major decisions on globalization even in cases where they are directly involved".

Hak (1999) stated that "The distribution of income between developing and developed countries has become less skewed because globalization in the integrated world economy has led to industrial growth in a limited number of developed countries. Besides that, many countries have been developed serious financial problem. It wills wider the income gap between developed and developing countries".

Every business looks for ways to increase costs. For manufacturing companies off shoring in other words, moving plant overseas to take an advantage of low cost of labor and raw material can be good option. In retail banking moving customer service department to low-cost country is an alternative way to lower operational costs. There are pros and cons to move customer service department to overseas. One of the main advantage is lowering employment cost for the bank. Employment is the one of the highest costs for the banks. On the other hand, time zone differences, extended wait time on the line, communication issues, ineffective solutions provided by customer service representatives, inadequate training and non-native speaker customer service representatives can be disadvantages for retail banks. Most of customers in United States expect to be helped by employee who lives in same country and same region. In the retail banking industry, there are banks moved their customer service department to low labor cost countries like China, Philippines, India. Some of them lost their customers because of poor customer service provided by outsourced customer service department.

China has 1.3 billion populations and this makes China highest population in the world. Because of high population in China, capital, labor, raw material etc. costs are low and this gives China competitive advantage on the global market. This would be an opportunity for American businesses which want to expand in China. On the other hand, this would be a critical threat for American business when Chinese companies enter American market. Because they can sell their products in lower price range while keeping the quality in same standard (Lin \& Lin, 2008). 
Expanding internationally is cost for company but if it is well-planned and done systematically, this will return as sales and profit to organization in a longer-term. There are also successful US companies which failed in overseas. In retail banking industry, successful expansion requires well-trained, knowledgeable employees and managers, adequate system, good location, high number of ATMs and successful marketing strategy in order to enter new market.

\section{Competitors}

Competition from both regional and foreign organizations are amongst top five threats (Pechet, 2012). When a competitor releases a new product or start a new marketing campaign or enter to new market, business needs to take actions to keep up and protect its place in the market or to compete with competitor. This is a critical threat for both business and managers. It is sales and marketing manager' responsibility to find a solution. Competition in the market effects customers buying decisions. When a competitor sells similar products for better price or launch a better product, this might cause loss of customers. But when competitor takes an action, this increases sales and marketing managers goals, expectations and work load. In order to keep existing customers, sales manager needs to find a way while increasing motivation of employees and satisfaction of customers.

In retail banking industry, one of the most effective marketing campaign is to offer free an account or when a customer satisfied some requirements, a customer would get some money. Refer a friend is also other effective marketing campaign in retail banking. When couple banks offer similar campaigns, it is hard for banks to gets customers attention. When there are similar options provided by financial institutions, customers go with other benefits that bank can offer. These includes, better interest rates, developed ATM network and customer service. Some banks started to get involved more community events. Increasing Corporate Social Responsibility- CSR awareness also one of the other techniques that banks use to get customers attention.

\section{Changing Customer Expectations}

In retail banking business, customers are key and everything starts with customers' satisfaction and loyalty. Customer expectations and satisfaction effected by competitors marketing decisions, usage of technology and social media, effects on globalization, employees' trainings, abilities and knowledge. Carper (2010) argues that " Customer service often decreases as companies pay for their goods and services to be provided from a foreign business".

In retail banking industry, factors like innovation, technology, new regulations, changing customer expectations, put sales margin on risk and makes banks to look for different ways to increase income. In the banking industry success based on retention of profitable customers, create life-long relationships, gain their trust, constantly meet their expectations for customers and for their household. For success, both products and service have to meet customers current and changing expectations (Opperman, 2011).

Meeting expectations requires in the first instance a comprehensive, 360-degree view of each customer, so when interactions are initiated there is enough understanding for an accurate response. Second, business leaders must consider the viability of instant responses from a human workforce. Matching expectations will have a considerable impact on customer lifetime value and churn, given $80 \%$ of consumers' report that immediate responses to requests influence their loyalty to a given brand (Johnson, 2017).

On the other hand, understanding target customers' needs and continue to meet with their expectations are important. When a bank does not pay close attention to customers changing needs over the time, this might lead to loss of loyal customers. Missing this step can be a threat for sales and marketing department. Marketing and sales departments constantly need to follow trends, make surveys and stay top of new technologies. Companies need to put themselves in customers' shoes to understand customers' perspective. When bank slook from customers stand point, banks' managers would understand importance of showing respect to customers. Businesses also want their products and services work properly. Companies need to meet consumers' changing expectations and not make consumers to find a better alternative. When customers' satisfaction level is changing, company needs to analyze what caused this change. It is important to figure out reasons before it leads to potential loss of business (Parke, 2012). New trends effected retail banking industry. Some of the customers do not prefer to go to the branch to make their usual banking transactions. It is more convenient for them to make certain transaction thru online or mobile banking. Banks need to watch changing customers need closely.

\section{Technology and Innovation}

In globalization world, technology plays vital role. If a bank does not invest in technology, this is a threat for sales and marketing department. Every day new technology takes over old methods. New technologies are more user friendly and attracts more customers. Investing in technology can be costly for organization but this would pay off in longer term. 
Cloud computing is becoming new trend. Information technology managers must learn this new technology to protect their company's interest. All of the innovative companies take an advantage of new technology and this would give them advantage in the market. Companies which fails to learn this new technology will be outdated soon and maybe their business fail (Linthicum, 2010).

In recent years, like other businesses, way of retail banking work changed. Almost all banks in United States use computer programs to conduct daily business activities. Usage of latest version of banking system provides better customer experience. The system which freeze and does not work efficiently takes longer time, this would cause dissatisfied customers. It is important to invest in good software program for retail banks. Recently some retailers in United States closed their stores and continue to do business online. This helps organizations to save on labor costs, rent, utility bills etc. On the other hand, since stores are not visual in daily life, marketing and sales department needs to work harder to attract customers.

Mobile banking and its features has become important for most of customers. Mobile banking provides transfers between accounts, see transaction history, make check deposit etc. Technology and innovation effects both online and mobile banking. There are customers see some banking features on some online or TV advertisement and ask for it. If the bank does not provide that feature yet, it may consider as old fashion bank. This is not a good reputation especially such a competitive retail bank industry. Marketing department needs to pay close attention to competitors products and service along with newest technology in the industry.

Researcher experienced that one customer changed primary bank because other bank offered online wire transfers and mobile deposit options. Other customer moved all of the funds to different institution because other institution offered chipped debit cards and more Atm network. This shows importance of technology and innovation.

Dealing with threats is one thing but if companies are not able to identify their competition than it can cause serious consequences. In recent years, technology and internet have change the way business is conducted. Many companies were caught napping with respect to competition coming from the internet. Retailers like Wal-Mart and Target are facing competition from online retailer Amazon.com. Companies see competition in a direct format. This direct format consists of industry structure, number of players, entry-exit barriers, business model and ability to globalize. Market looks at competition in much more holistic manner where different products can satisfy a similar need (Management Study Guide, 2017).

\section{Role of Management}

Sales and marketing managers need to use skills, abilities, position, resources and experiences to reduce negative effects of treats before they become weaknesses. Swot analysis is a great tool for manages to identify strengths, weaknesses, threats and opportunities. Sales and marketing managers can take an advantage of strengths and opportunities while deciding marketing plan and campaign. Not all of treats can be prevent by managers' efforts. There are external treats that sales and marketing manager does not have control over.

It is also important for managers to educate themselves and attend trainings. Managers also need to communicate efficiently with their employees to work as a strong and successful team. Sales and marketing managers need to communicate with upper management to have them make budget for marketing campaigns.

Senior managers often describe the working relationship between Sales and Marketing as unsatisfactory. The two functions, they say, under communicate, underperform, and over complain. Not every company will want to-or should - upgrade from defined to aligned relationships or from aligned to integrated relationships. But every company can and should improve the relationship between Sales and Marketing. Carefully planned enhancements will bring salespeople's intimate knowledge of your customers into the company's core (Kotler, Rackham \& Krishnasamy, 2006).

\section{Conclusions}

The purpose of this research was to define most important treats in sales and marketing department and to analyzesales and marketing departments' role to overcome most important treats in retail banking industry. Competitors, globalization, technology and changing customer expectations are the most important threats for sales and marketing department management. If a retail bank use technology efficiently and follows-up new trends occasionally, this would be help the bank stay competitive in the market.

Globalization has both advantages and disadvantages. While it causes high unemployment rate in developing countries, developed countries take an advantage of low cost labor and raw material. In retail banking industry, globalization might have disadvantages. Most of customers would not feel comfortable when their money is managed by someone from overseas or when a customer calls a call center, customers are not happy to hear non-native speakers over the phone. All these things adds up quickly and affects bank's customer portfolio. 
Businesses cannot survive without customer. Retail banks need to watch trends and follow customers' expectation to stay in business. Managers need to educate themselves about threats and how to overcome them. Managers also need to watch trends closely, attend trainings, increase communication with customers, listen to customers, get feedbacks, check competitors' behaviors in market. If a manager cannot identify a threat in early stages, a threat can become a weakness. It would be harder to fix weaknesses.

As a result, all threats are related. Each threat affect other one. While globalization has effects on changing customer needs, technology also has effects on customers. Failure of meeting customers need effects competitiveness. This makes competitors stronger. It may not enough to take measures for just threat. It is important for managers to understand all these threats work together and ignoring one of them can have domino effect.

\section{References}

Carper, T. (2010). The Threat of Globalization. Amsterdam: IOS Press. pp9

Hak, M. (1999). Globalization: Threat or Opportunity To The Developing Countries? Retrieved from https://www.ukessays.com/essays/economics/globalization-threat-or-opportunity-to-the-developing-countrieseconomics-essay.php?cref=1

Johnson, N. (2017). How Your Customers' Expectations Have Changed in the Age of the Customer? Salesforce Leadership and Innovation.

Kotler, P., Rackham, N. \& Krishnaswamy, S. (2006). Ending the War Between Sales and Marketing. Harvard Business Review.

Lin, C. C., \& Lin, J. (2008). Capitalism in contemporary china: Globalization strategies, opportunities, threats, and cultural issues. Journal of Global Business Issues, 2(1), 31-40. Retrieved from https://login.libproxy.edmc.edu/login?url=https://search-proquestcom.libproxy.edmc.edu/docview/223745597?accountid=34899

Linthicum, D. S. (2010). Value of cloud computing. The Open Source Business Resource, 5-11. Retrieved from https://login.libproxy.edmc.edu/login?url=https://search-proquestcom.libproxy.edmc.edu/docview/1695041774?accountid=34899

Management Study Guide. (2017). Competition Strategy - Dealing with the Competition. Management Study Guide Marketing Management.

Opperman, G. (2011). Relentless focus on customer satisfaction: Key to future retail bankingsuccess. Accountancy $S a$, 28. Retrieved from https://login.libproxy.edmc.edu/login?url=https://search-proquestcom.libproxy.edmc.edu/docview/900378250?accountid=34899

Parke, J. (2012). Managing customer expectations. Applied Clinical Trials, 21(10), 40-42,44.

Pechet, N. (2012). Your local competitor: A threat in emerging markets? Pharmaceutical Executive, 32(10), 68-69. Retrieved from https://login.libproxy.edmc.edu/login?url=https://search-proquestcom.libproxy.edmc.edu/docview/1221233916? accountid=34899

Zedillo, R. (2007). Introduction to globalization: political and economic perspectives for the new century, Rowman \& Littlefield, Lanham, MD 